\title{
Physiotherapy Practice postoperative blepharoplasty: experimental study
}

\author{
Taís Ingrid de Lima Silveira', Rodrigo Marcel Valentim da Silva², Luis Gonzaga Araújo Neto², \\ Ruth Gabryella Praxedes Fernades ${ }^{4}$, Patrícia Froes Meyer ${ }^{5}$
}

\begin{abstract}
Introduction: Blepharoplasty word is of Greek origin (blepharos refers to the eyelids, and plasty is on the form, shape), used to call the eyelid rejuvenation surgery. The physical therapy can prevent or reduce many of the complications caused by blepharoplasty, such as swelling, bruising, hematoma, keloid, among others. Objective: This project aims to observe the physiotherapy performance in the post-blepharoplasty, assessing the general condition of the patient, as the possible complications of surgery. Methods: This study is characterized as a clinical trial and quasi-experimental. The survey sample contains 8 participants $(n=8)$. Inclusion criteria were patients who had undergone blepharoplasty surgery at the Institute of Vision, female, with a mean age of 60.1 years, menopausal and time availability in the morning and / or afternoon. Exclusion criteria were patients who missed 3 or more sessions, presence of eye diseases such as conjunctivitis, exacerbated pain in the surgery area, infection in the incision area and to provide dehiscence. They started treatment in the second postoperative day, being applied to pumping technique with the use of gauze on the upper eyelid region, manual lymphatic drainage (MLD) and kinesiotherapy in a 40 minute session, with the total of 10 sessions. Results: The level of education of patients and their professions was observed to changes in the postoperative period, the quality of life of patients and duration of the presence of complications. Conclusion: It is suggested that physical therapy in the daily early postoperative period of blepharoplasty may have contributed to avoid complications and that blepharoplasty does not affect the quality of life.
\end{abstract}

Keywords: Blepharoplasty. Physiotherapy. Postoperative.

\section{INTRODUCTION}

Usually, aging changes are perceived primarily around the eyes. Currently, there are various techniques on different principles to correct deformities eyelid appearing with the aging process. Congenital abnormalities, trauma or aging itself of anatomical structures often require conducting a blepharoplasty. ${ }^{(1,2)}$

Blepharoplasty word is of Greek origin (blepharos refers to the eyelids, and plasty is on the form, shape), used to call the eyelid rejuvenation surgery. This surgery may be performed alone or in combination with other procedures which complement the treatment of the signs of aging of that region. It should aim not only to the aesthetic benefits, but also to preserve the aspect functional of the eyelids. ${ }^{(3)}$

Blepharoplasty has been performed very often due to the appreciation of the cosmetic surgery. Its complications are uncommon and rarely permanent, with functional or aesthetic consequences. Among the problems which may arise after blepharoplasty, the most common complications are ptosis of the upper eyelid, lagophthalmos caused by incorrect resection of skin, scars, preg abnormalities eyelid, retraction and ectropion. ${ }^{(4)}$

The physiotherapy treatment may prevent or reduce many of the complications caused by blepharoplasty, such as edema, bruising, hematoma, keloid, among others, which may be used therapeutic methods such as lymphatic drainage, massage therapy and kinesiology, enabling the reduction of these possible complications. ${ }^{(5)}$ Postoperatively the time of intervention varies according to the surgery and the procedure performed. The reduction treatment for edema made by lymphatic drainage is indicated for all surgical techniques and allows the early treatment. ${ }^{(6)}$

The role of physiotherapy in blepharoplasty postoperative already exists, however, due to lack of scientific studies on this important issue in the context of plastic surgery and the gradual increase in interest for rejuvenation by the world's population, it has aroused the interest in deepening this issue.

Corresponding author: Rodrigo Marcel Valentim da Silva. Adress: Rua Nossa Senhora de Fátima, 312b, Alecrim. CEP: 59030080. Natal (RN), Brazil. Phone: (84) 991645644. E-mail: marcelvalentim@hotmail.com

2. Master in Physiotherapy, Universidade Federal do Rio Grande do Norte, Natal (RN), Brazil.

Full list of author information is available at the end of the article.

Financial support: Self-financing.

Submission date 15 August 2016; Acceptance date 8 November 2016; Publication date 1 December 2016 
The aim of this study is to observe the physiotherapy performance in the post-blepharoplasty, assessing the general condition of the patient, as the possible complications of surgery. Moreover, it will be described the performed therapies and compared with their results.

\section{METHOD}

This study is experimental, quasi-experimental type. The work was submitted to the Research Ethics Committee and was performed after its approval. The study follows the CONSORT recommendations for experimental studies. It was held at the Clinical Institute of Vision, located in Natal, RN.

The population consisted of volunteer patients in a state of post-surgical blepharoplasty from the Clinic mentioned above, and the research sample comprised of eight participants who agreed to participate by submitting to the physiotherapy treatment.

We used the following inclusion criteria: patients who had undergone blepharoplasty surgery at the Institute of Vision, female, with a mean age of 60.1 years, menopausal and time availability in the morning and/or afternoon. Exclusion criteria were: patients who lacked service during three or more, the presence of eye diseases such as conjunctivitis, exacerbated pain in the surgery area, infection in the incision area and to provide dehiscence in surgical suture.

The materials used for the collection of data were: a portable camera Canon brand power shot model elph 300, 12.1 mega pixels, gauze, and a questionnaire adapted from the facial evaluation protocol (FEP). This questionnaire was divided into two evaluations, one which was held on the first day of service and the other evaluation was performed daily. Some questions concerning the evaluation of quality of life were adapted from Celluqo ${ }^{\circledR}$, evaluation tool the quality of life for patients with cellulitis.

The research was conducted at the Clinical Institute of Vision from December 2015 to June 2016. After contact with the ophthalmologist surgeon and authorization of clinical, the patients were selected according to the inclusion and exclusion criteria. Later, the Consent and Informed was given to the participants. They underwent an adapted questionnaire, which was assessed by a clinical history and physical examination taken into consideration the edema, pain, bruising, fibrosis and sensitivity. Afterward, photos were recorded, always before the consultations. After the surgery, the treatment initiated on the second day after surgery, being applied to pumping technique with the use of gauze in the region of the upper and lower eyelid, manual lymphatic drainage (MLD) of the neck and face, using the Godoy technique and finally it was held the scar stretching in the upper eyelid, where the physiotherapist slides over the entire path of the scar upward with gentle pressure after the removal of stitches, in a 40-minute session, and the total 10 sessions.
The techniques used are illustrated in Figures 1,2 and 3.

Data analysis was performed from the information of the questionnaires, which were entered and tabulated in a database for statistical analysis. The databases were built on Microsoft Excel 2003. A descriptive analysis was performed, with a mean and standard deviation of variables.

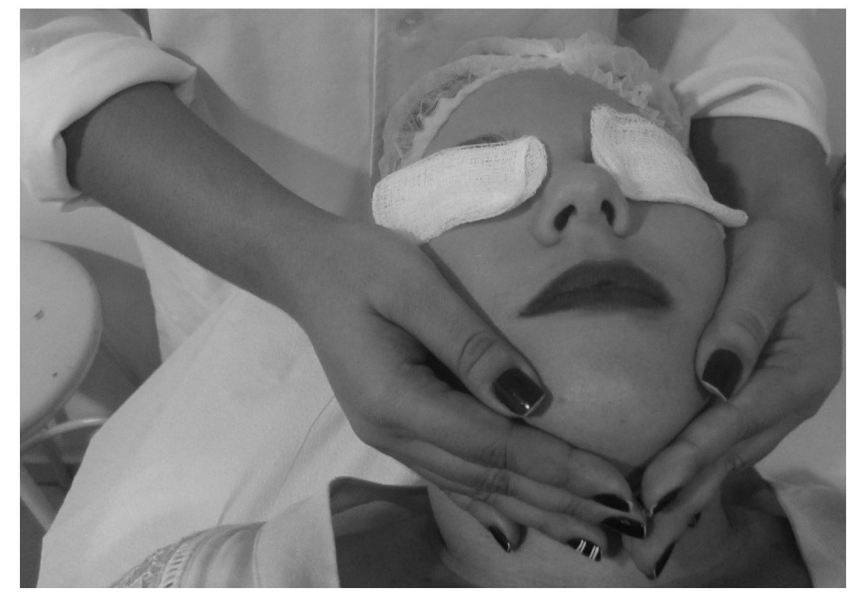

Figure 1. Manual Lymphatic Drainage in the neck and face.

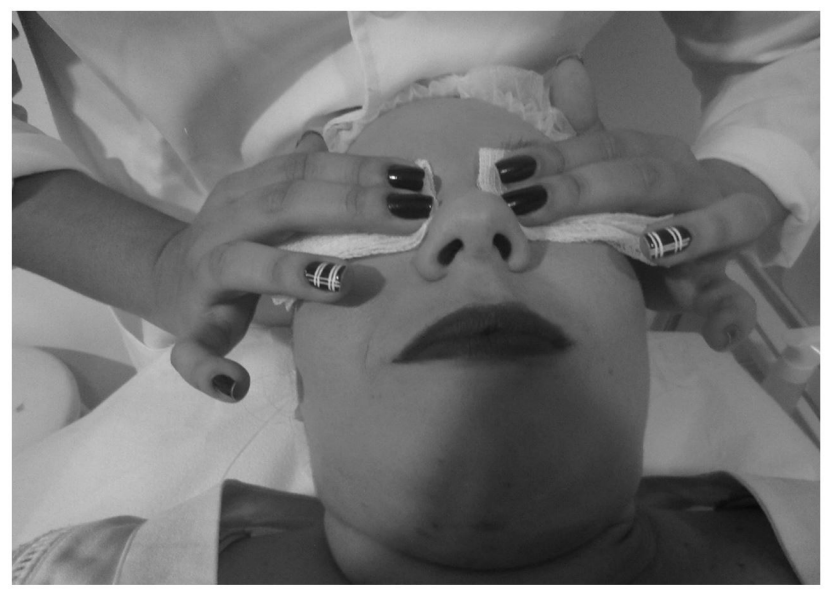

Figure 2. Pumping technique in the upper and lower eyelid region.

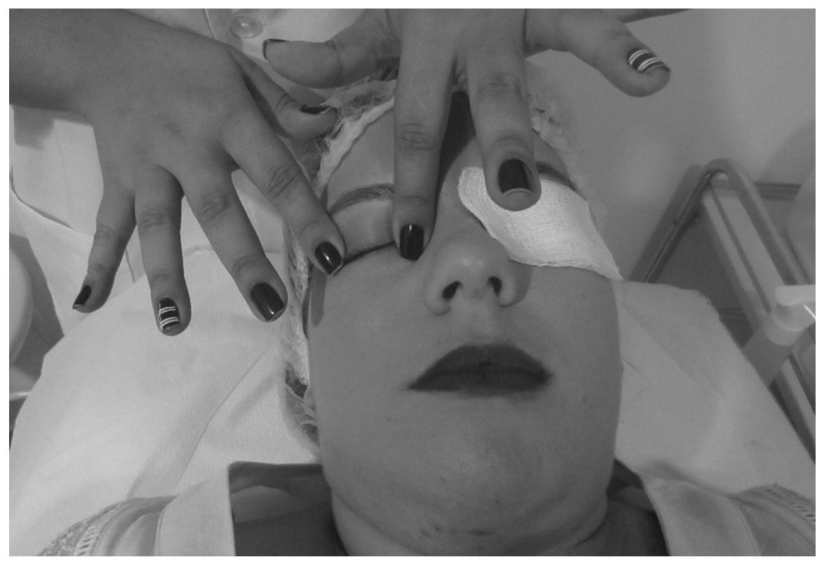

Figure 3. Stretching the surgical scar after the removal of stitches. 


\section{RESULTS}

In the present study, we observed the level of education of patients and their occupations, the alterations in the postoperative period, the quality of life of patients in this period and complications time.

Table 1 shows that most of the patients have incomplete elementary school (37.5\%). In relation to the occupation of the patients, the majority are housewives (37.5\%) as shown in Table 2.

In table 3 it was observed the changes which may occur in blepharoplasty immediate postoperative period, according to the questionnaire adapted facial assessment protocol (FAP), however, patients showed only swelling, pain and bruising, and $75 \%$ (majority) of them had edema and ecchymosis.

Table 4 shows the progression of the disease according to the patient and it may be interpreted as blepharoplasty affects the quality of life of operated patients. It was observed that in 5 patients (62.5\%) blepharoplasty not affect the quality of life, 1 patient (12.5\%) the blepharoplasty affects a little the quality of life and in 2 patients (25\%) the blepharoplasty reasonably affect the quality of life. And found that most patients do not think that blepharoplasty surgery affects the quality of life.

It is observed that if the sum of the items evaluated is between 8 and 16 points, blepharoplasty does not affect the quality of life of the patient, if it is between 16 and 24 points, blepharoplasty little affect the quality of life, as if between 24 and 32 points blepharoplasty reasonably affect the quality of life, and if the result is between 32 and 40 points blepharoplasty greatly affects the quality of life of the patient.

Regarding the time of presence of secondary blepharoplasty complications, it was observed that the edema remained for 8 days in 2 patients (25\%), 7 days in 3 patients (37.5\%) and 5 days in 3 patients (37.5\%), ecchymosis remained for 10 days in 1 patient (12.5\%), 8 days in 1 patient (12.5\%), 7 days in 3 patients (37.5\%), 5 days in 1 patient (12.5\%) and 4 days in 2 patients (25\%), the pain was present 2 days in 2 patients (25\%), 1 day in 2 patients ( $25 \%$ ) and no day in 4 patients $(50 \%)$, the sensitivity was maintained in all 8 patients (100\%) during the 10 days of care (figures 4 and 5).

\section{DISCUSSION}

This study had the participation of eight (8) women, the youngest was 52 years old and the oldest was 69 years old. The education degree was observed, in addition to the occupations, a significant index was checked in patients who did not complete their school studies and consequently exert a function employment which does not require a great complexity of knowledge.

The lower the level of education of individuals, the higher the anxiety score preoperatively, and we observed that educated patients were less anxious in the preoperative period, however, this difference was not observed during follow-up after surgery. ${ }^{(7)}$ Preoperative guidelines on care,
Table 1. Educational level of patients undergoing post-operative blepharoplasty

\begin{tabular}{lcccc}
\hline \multicolumn{1}{c}{ Education } & Frequency & Percentage & $\begin{array}{c}\text { Valid } \\
\text { percentage }\end{array}$ & $\begin{array}{c}\text { Cumulative } \\
\text { percentage }\end{array}$ \\
\hline $\begin{array}{l}\text { Incomplete } \\
\text { Elementary } \\
\text { School }\end{array}$ & 3 & 37.5 & 37.5 & 37.5 \\
$\begin{array}{l}\text { Complete } \\
\text { Elementary }\end{array}$ & 1 & 12.5 & 12.5 & 50,0 \\
$\begin{array}{l}\text { School } \\
\text { Incomplete }\end{array}$ & 1 & 12.5 & 12.5 & 62.5 \\
$\begin{array}{l}\text { High School } \\
\text { Complete High }\end{array}$ & 2 & 25.0 & 25.0 & 87.5 \\
School & 1 & 12.5 & 12.5 & 100.0 \\
$\begin{array}{l}\text { Incomplete } \\
\text { College }\end{array}$ & 100.0 & 100.0 & \\
\begin{tabular}{l} 
Total \\
\hline
\end{tabular} & 8 & 10.0 & & \\
\hline
\end{tabular}

Table 2. Occupation incidence of patients undergoing post-operative blepharoplasty

\begin{tabular}{lcccc}
\hline Occupation & Frequency & Percentage & $\begin{array}{c}\text { Valid } \\
\text { percentage }\end{array}$ & $\begin{array}{c}\text { Cumulative } \\
\text { percentage }\end{array}$ \\
\hline Housemaid & 2 & 25.0 & 25.0 & 25.0 \\
Housewife & 1 & 12.5 & 12.5 & 37.5 \\
Manicure & 1 & 12.5 & 12.5 & 50.0 \\
Nurse & 1 & 12.5 & 12.5 & 62.5 \\
Secretary & 1 & 12.5 & 12.5 & 75.0 \\
Professor & 1 & 12.5 & 12.5 & 87.5 \\
Retired & 1 & 12.5 & 12.5 & 100.0 \\
Total & 8 & 100.0 & 100.0 & \\
\hline
\end{tabular}

Table 3. Changes present in the immediate postoperative period

\begin{tabular}{lcccc}
\hline $\begin{array}{l}\text { Changes in the } \\
\text { postoperative }\end{array}$ & Frequency & Percentage & $\begin{array}{c}\text { Valid } \\
\text { percentage }\end{array}$ & $\begin{array}{c}\text { Cumulative } \\
\text { percentage }\end{array}$ \\
\hline $\begin{array}{l}\text { Edema and } \\
\text { ecchymosis }\end{array}$ & 6 & 75.0 & 75.0 & 25.0 \\
$\begin{array}{l}\text { Edema, pain } \\
\text { and bruising }\end{array}$ & 2 & 25.0 & 25.0 & 75.0 \\
Total & 8 & 100.0 & 100.0 & \\
\hline
\end{tabular}

Table 4. Quality of life assessment during blepharoplasty postoperative according to the patient report

\begin{tabular}{ccr}
\hline Patient & $\begin{array}{c}\text { Total } \\
\text { score }\end{array}$ & Result \\
\hline A & 8 & Blepharoplasty does not affect the quality of life \\
B & 8 & Blepharoplasty does not affect the quality of life \\
C & 19 & Blepharoplasty affects a little the quality of life \\
D & 25 & Blepharoplasty reasonably affects the quality of life \\
E & 13 & Blepharoplasty does not affect the quality of life \\
F & 26 & Blepharoplasty reasonably affects the quality of life \\
G & 11 & Blepharoplasty does not affect the quality of life \\
H & 8 & Blepharoplasty does not affect the quality of life \\
\hline
\end{tabular}




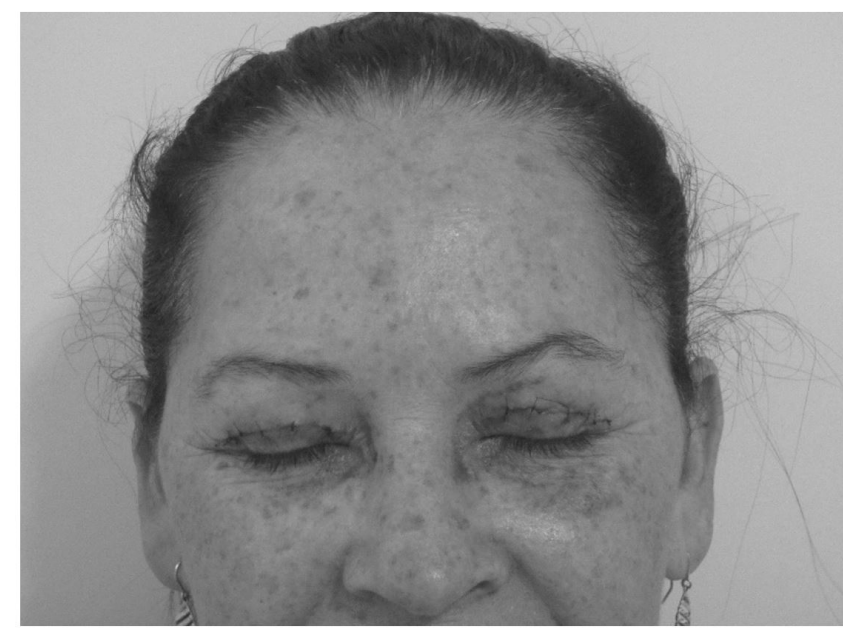

Figure 4. [[Q2: Q2]] Patient presenting bruising on the upper eyelid on the 7th day of Postoperative

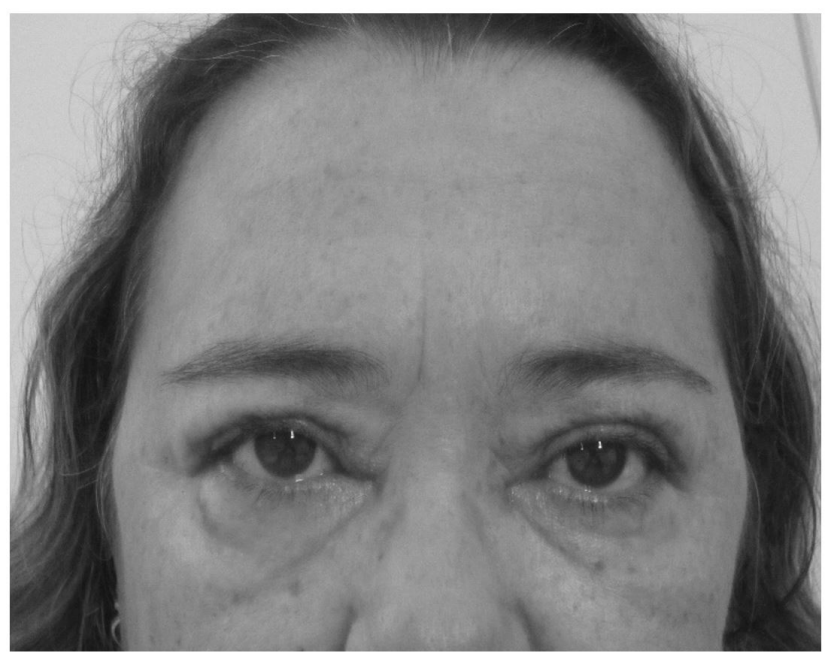

Figure 5. [[Q3: Q3]]Patient with edema in the upper eyelids in the 7th day of Postoperative

techniques, risks and benefits should be held in accessible language, in order to make a quietest moment, reflecting on the good recovery of the patient, preventing and minimizing the stressors of surgery. ${ }^{(8)}$

In this case, despite lower education and knowledge of the volunteers of this study, it was not detected significant change in relation to quality of life and has not been reported level of anxiety in the preoperative period, not coinciding with the other study. Physiotherapists perform a key role in the preparation and rehabilitation of individuals who are undergoing surgical procedures. In addition to having a large arsenal of techniques, the physiotherapist, notoriously, has been one of the professionals who is alongside the patients ${ }^{(7)}$. The volunteer group in this study had a physiotherapy daily monitoring, being important to answer questions, which probably assured the same during this phase, even when dealing with a group of people who have less knowledge about blepharoplasty and its complications.

Complications in blepharoplasty postoperative are not common and when they occur are usually mild and transient, such as hematoma and chemosis, defined as edema of the bulbar conjunctiva or fornix. However, sometimes it may be permanent, such as blindness, or require another approaches to surgical correction, as ectropion and ptosis. The incidence of chemosis after blepharoplasty in the literature goes from 4 to $12.6 \%$, which was not observed in any of the cases this present study. ${ }^{(9,10)}$ The hematoma, edema and postoperative pain are the direct result of physical trauma of surgery and subsequent inflammatory response, which may be observed in any other surgery due to tissue injury, which will lead to an inflammatory response, triggering some signs of inflammation which they are not necessarily specifically linked to blepharoplasty ${ }^{(11)}$ Lesser vascular trauma, less discomfort, edema and bruising the patient will may present at this stage. The lower the rate of complications in the postoperative period, faster will be the recovery and satisfaction with the results ${ }^{(12)}$.

In the physical evaluation of patients, it was seen that they had hematoma, bruising and pain, which as stated above, they are expected symptoms postoperatively. No cases of infection, dehiscence, hematoma, petechiae, vibice, scar retraction, hypertrophic scarring, fibrosis, and keloids. Dry eye syndrome is the most common adverse effect after blepharoplasty surgery, which was not observed in this study ${ }^{13}$. Postoperatively, evidence of pain, bruising and edema consistent with normal postoperative period for the first few weeks. ${ }^{(14,15)}$ The physiotherapy has the technique for edema reduction the manual lymphatic drainage, in which when applied correctly achieves satisfactory results, providing relief from edema and thus relieve pain by decreasing nerve endings in compressions.

The surgical scar is an aspect of wide concern and essential to a better result of cosmetic surgery. Occurrences of hypertrophy, flares and asymmetries are related to excessive traction flap or when the initial incision is compensated, at the end of surgery, to the side or resections and progressive sutures. In this case, the physiotherapy is limited to minimize, if possible, the tension on the flap through the early control of edema and adequacy of metabolic and elastic properties of the skin. Mechanical strain applied in the healing tissue promote organization of collagen bundles in a more natural manner, with more elasticity than when not apply the strain. ${ }^{(16)}$

Therapeutic exercise is a significant resource in most physiotherapy plans, in order to regain functionality and reduce disability. It has activities which prevent complications and reduce the hospital use of resources during or after surgery. Physiotherapy has various resources to be used in the postoperative period, but among the other features, this present study used only three techniques for observing from 
evaluations of patients that they only had, as complications of blepharoplasty, edema, ecchymosis and pain, thus, the manual lymphatic drainage and pumping performed in this study were the most suitable techniques for the treatment of patients, such as prevention of other complications, e.g., fibrosis and scar adhesion was carried elongation of the surgical scar after the removal of stitches. ${ }^{(17)}$

Blepharoplasty minimally affects the quality of life of patients. This result encourages the realization of this type of surgery. Moreover, it demonstrates that the patient enjoys the result of blepharoplasty. It was observed in this study that most patients who undergo surgery did not feel that blepharoplasty affect the quality of life, there was no case that blepharoplasty greatly affect the quality of life of the patient. ${ }^{(18)}$

Another important point was the time of presence of complications from surgery, it was seen that the maximum time with the presence of edema were eight (08) days and the minimum was five (05) days, the bruising maximum time observed were the ten (10) days of care and the minimun were four (04) days and the sensitivity was maintained for all ten (10) days of care in all patients. Dermato functional physiotherapy has been essential in monitoring the progress of patients undergoing plastic surgery because not only the manual lymphatic drainage technique, but also its range of therapeutic resources. These aim to prepare the tissue for the procedure, as well as speed up post-operatory recovery. Dermato functional physiotherapy acts in the treatment of dermatological disorders and diseases of the skin, allowing this tissue to be more standardized as possible. Skin disorders to occur at different ages and, in the elderly, they become more common due to loss of integrity of its functionality, as well as in other tissues. ${ }^{(19,20)}$

\section{CONCLUSION}

It is suggested that physiotherapy in the daily early postoperative period of blepharoplasty may have contributed to avoid complications and that blepharoplasty does not affect the quality of life.

\section{AUTHOR'S CONTRIBUTION}

TILS, LGAN, RGPF: Evaluation and intervention of the volunteers (Data collection), writing of the work; RMVS, PFM: Data Analysis, Discussion and Guidance of work.

\section{CONFLICTS OF INTEREST}

There was no conflict of interest in the research.

\section{AUTHOR DETAILS}

1. Student of Physiotherapy, Centro Universitário do Rio Grande do Norte (UNIRN), Natal (RN), Brazil. 3. Student of Physiotherapy, Universidade Potiguar (UNP/RN), Natal (RN), Brazil. 4. Physiotheraphy, Natal (RN), Brazil. 5. Professor of Physiotherapy, Universidade Potiguar (UnP) e Centro Universitário do Rio Grande do Norte (UNI-RN), Natal (RN), Brazil.

\section{REFERENCES}

1. Ishizuka CK. Autoestima em pacientes submetidas a blefaroplastia. Rev. bras. cir. Plás 2012;27(1):31-36.

2. Doncatto L, Schwantz PE. Blefaroplastia estética: resultados, complicações e a sua prevenção. Canoas, 2012.

3. Borges FS. Dermato-funcional: modalidades terapêuticas nas disfunções estéticas. 2ed, São Paulo, Cap 19, p. 437- 498, 2010.

4. Artioli SS, Valezi VG, Passos W. Complicações da blefaroplastia superior. Rev. bras.oftalmol. 2012;71(4):253-255.

5. Meyer PF, Barros HMM, Santos ML, Medeiros JO, Nunes SL. Protocolo fisioterapêutico para o pós-operatório de blefaroplastia. Ter Man. 2010;8(35):60-5.

6. Milani GB, Silvia MAJ, Farah EA. Fundamentos da Fisioterapia dermatofuncional: revisão de literatura. Fisioterapia e pesquisa. 2006;13(1):37-43.

7. Garbossa A, Maldaner E, Mortari DM, Biasi J, Leguisamo CP. Efeitos de orientações fisioterapêuticas sobre a ansiedade de pacientes submetidos à cirurgia de revascularização miocárdica. Rev Bras Cir Cardiovasc. 2009;24(3):359-366.

8. Perrando M, Beuter M, Brondani CM, Roso CC, dos Santos TM, Predebon GR. O preparo pré-operatório na ótica do paciente cirúrgico. R. Enferm. UFSM. 2011;1(1):61-70.

9. Patrocinio TG, Loredo BAS, Arevalo CEA, Patrocinio LG, Patrocinio JA. Complications in blepharoplasty: how to avoid and manage them. Braz. j. otorhinolaryngol. 2011;77(3):322-327.

10. Basile FVD'Angieri. Correção das retrações palpebrais secundárias à blefaroplastia. Rev. bras. cir. Plást. 2011;26(2):228-242.

11. Jones BM, Grover R, Southwell-Keely JP. Post-operative hilotherapy in SMAS-based facelift surgery: a prospective, randomised, controlled trial. J Plast Reconstr Aesthet Surg. 2011 Sep;64(9):1132-7.

12. Meyer PF, Grunewald CC, Afonso YA. Estudo comparativo entre pósoperatório de pacientes submetidos à lipoaspiração tradicional e vibrolipoaspiração. Revista FisioBrasil. 2004;62:11-14.

13. Schellini SA, Preti RC, Yamamoto RK, Padovani CR, Padovan CRP. Dimensões palpebrais antes e após blefaroplastia superior: avaliação quantitativa. Arq. Bras. Oftalmol. 2005;68(1):85-88.

14. Zanella PSM, de Castro CC, Boechat CEJ, Aboudib JH. Tratamento das rugas glabelares por abordagem transpalpebral dos músculos corrugadores do supercílio. Revista Brasileira de Cirurgia Plástica. 2001;21(2):97-101.

15. Corrêa VSML. Intervenção fisioterapêutica nos sinais e sintomas do pósoperatório de blefaroplastia. [Tese] (2011).

16. Macedo ACB, Oliveira SM. A atuação da fisioterapia no pré e pósoperatório de cirurgia plástica corporal: uma revisão de literatura. Saúde. 2014;1:5.

17. da Silva RMV, Cordeiro LF, Figueirêdo LSM, Almeida RAL, Meyer PF. O uso da cinesioterapia no pós-operatório de cirurgias plásticas. Ter Man. 2013;11(51):129-134.

18. Paixão MP, Miot HA, Machado Filho CDS. Avaliação do impacto da blefaroplastia superior na qualidade de vida utilizando questionário padronizado (Qblefaro): estudo piloto. An. Bras. Dermatol. 2008;83(1):3237.

19. Flores A, Brum KO, Carvalho RM. Análise descritiva do encaminhamento médico a tratamentos fisioterapêuticos dermato-funcionais nos períodos pré e pós-operatório de cirurgias plásticas cosméticas. Mundo saúde 2011;35(4):408-14.

20. Caloy L. Necessidades da atuação da fisioterapia dermato-funcional em uma instituição de longa permanência de idosos. Dissertação de Mestrado. Pontifícia Universidade Católica do Rio Grande do Sul (2011). 